\title{
A experiência lúcida em Orides Fontela
}

Adilson Citelli*

Professor titular do Departamento de Comunicações e Artes da ECA/USP, onde ministra cursos de graduação e pós-graduação. Orienta dissertações e teses nas áreas de Comunicação e Linguagem, com ênfase nas subáreas Comunicação/Educação, Comunicação/Linguagem. É coeditor da revista Comunicação \& Educação, bem como pesquisador $1 C$ do CNPq**.

E-mail: citelli@uol.com.br

Orides Fontela nasceu em 1940, em São João da Boa Vista (SP), filha de Álvaro Fontela, marceneiro, e de Lurinda Teixeira Fontela. Seus primeiros poemas foram publicados no ano de 1956, em um jornal de sua cidade natal, Município. Ao reencontrar David Arrigucci Jr., com quem privara de amizade na infância, Orides apresenta alguns dos poemas que havia escrito. O crítico literário, reconhecendo a qualidade dos textos, faz com que sejam publicados no Suplemento Literário do jornal O Estado de S. Paulo.

Em 1967, por influência de amigos, ingressa no curso de Filosofia da Universidade de São Paulo. Em 1969, é lançado o seu primeiro livro de poemas, Transposição. Em sequência são publicados Helianto (1973), Alba (1983), pelo qual recebe o Prêmio Jabuti, e Rosácea (1986). Em 1988, Augusto Massi reúne toda a obra da poeta no livro Trevo. Em 1996, o livro Teia, reunião de toda a sua obra, recebe o Prêmio concedido pela APCA - Associação Paulista de Críticos de Arte. Em 2 de junho de 1998, a poeta falece sozinha num sanatório em Campos do Jordão (SP). Por fim, em 2006, seu livro Poesia reunida é lançado.

Orides Fontela, apesar de sua difícil personalidade, foi rodeada de grandes admiradores, tais como Davi Arrigucci Jr., Antonio Candido, Augusto Massi, Décio de Almeida Prado, José Miguel Wisnik. Segundo Davi Arrigucci Jr. ${ }^{1}$, "era uma menina um pouco peculiar, como foi a vida inteira, pois não sabia controlar os risos e as lágrimas". A intensidade com que viveu seus sentimentos é facilmente reconhecida na poesia que produziu, só que de forma mais contida e depurada. A exemplo de João Cabral de Melo Neto, a poeta molda a palavra como um artesão trabalha sua obra, transformando-a em poesia. Contudo, diferentemente de João Cabral, que apresenta uma poesia seca, dura e cortante, na obra de Orides Fontela é possível entrever "um desespero transfigurado e seguro nas imagens que explodem" ${ }^{2}$. Com o objetivo de ilustrar a obra de Orides Fontela, segue uma pequena seleção de poemas publicados ao longo de sua obra.

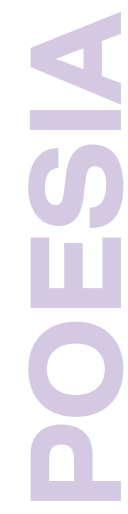

* Com a colaboração de Cristine Vargas (revista Comunicação \& Educação - ECA/USP e FFLCH/ USP).

** É autor de inúmeros artigos e livros, dentre os quais se destacam: Linguagem e persuasão (Ática: 1994); Comunicação e educação: a linguagem em movimento (Senac: 2000); Palavras, meios de comunicação e educação (Cortez: 2006).

1. ARRIGUCCI JR., Davi. $\mathrm{Na}$ trama dos fios, tessituras poéticas. Jandira: Revista de Literatura, Juiz de Fora, n. 2, p. 113, out. 2005.

2. Ibid., p. 115. 
comunicação \& educação • Ano XVI • número 1 • jan/jun 2011

\section{POEMAS}

Tempo

O fluxo obriga

qualquer flor

a abrigar-se em si mesma

sem memória.

O fluxo onda ser

impede qualquer flor

de reinventar-se em

flor repetida.

O fluxo destrona

qualquer flor

de seu agora vivo

e a torna em sono.

$\mathrm{O}$ universofluxo

repele

entre as flores estes

cantosfloresvidas.

(Transposição, 1969)

\section{Fala}

Tudo

será difícil de dizer:

a palavra real

nunca é suave.

Tudo será duro:

luz impiedosa

excessiva vivência

consciência demais do ser.

Tudo será

capaz de ferir. Será

agressivamente real.

Tão real que nos despedaça.

Não há piedade nos signos

e nem no amor: o ser

é excessivamente lúcido

e a palavra é densa e nos fere.

(Toda palavra é crueldade.)

\section{REFERÊNCIAS BIBLIOGRÁFICAS}

ARRIGUCCI JR., Davi. Na trama dos fios, tessituras poéticas. Jandira: Revista de Literatura, Juiz de Fora, n. 2, p. 113-123, out. 2005.

FONTELA, Orides. Poesia reunida [1969-1996]: Orides Fontela. São Paulo: Cosac Naify; Rio de Janeiro: 7 Letras, 2006.

\section{Endereço eletrônico}

Orides Fontela. Disponível em: <http://www.releituras.com/ofontela_menu. asp>. Acesso em: 6 out. 2010. 